\title{
Survival and viability of ascospores of Erysiphe necator in Austrian vineyards
}

\author{
M. Redl • S. Möth • E. Koschier • B. Spangl • \\ S. Steinkellner (1)
}

Accepted: 25 December 2020/Published online: 7 January 2021

(C) The Author(s) 2021

\begin{abstract}
Grape powdery mildew caused by Erysiphe necator is a limiting factor in grape production. In order to develop effective management strategies, the factors influencing the survival of the fungus need to be identified and characterized accordingly. For this purpose, we focused on the effect of weather conditions during overwintering on the survival and viability of ascospores. In spring 2017 and 2018, grape leaf litter and bark samples were collected and examined to determine the density of chasmothecia and the viability of ascospores in various Austrian vine growing regions. There were obvious differences in the amounts of chasmothecia between both years and all examined vineyards. Lower quantities of chasmothecia were detected on the exfoliating bark compared to leaf litter, with up to $37 \%$ of chasmothecia containing viable ascospores. In comparison, chasmothecia from leaf litter showed a lower viability (up to $5 \%$ ). The number of viable ascospores per head of vine ranged from 0 to 351 and from 0 to 251 in 2017 and 2018, respectively, and showed partly a strong variation within one location in both years. The infectivity of ascospores on detached leaves was confirmed. In a survival experiment, chasmothecia, when incubated at $7{ }^{\circ} \mathrm{C}$, released more
\end{abstract}

\footnotetext{
M. Redl · S. Möth · E. Koschier •

. Steinkellner $(\bowtie)$

Institute of Plant Protection, University of Natural Resources and Life Sciences, Gregor-Mendel-Straße 33, A-1180 Vienna, Austria e-mail: siegrid.steinkellner@boku.ac.at

\section{B. Spangl}

Institute of Statistics, University of Natural Resources and Life Sciences, Peter-Jordan-Straße 82, A-1190 Vienna, Austria
}

viable ascospores than chasmothecia incubated at $17^{\circ} \mathrm{C}$. After an incubation period of 30 weeks, only chasmothecia stored at the lower temperature contained viable ascospores. However, the mean temperature differences of 0.1 to $1.2{ }^{\circ} \mathrm{C}$ during the period of formation of chasmothecia to bud break in both years and six investigated areas did not explain differences in the viability of the ascospores. Differences in vineyard management seem to be of particular importance here.

Keywords Erysiphe necator . Chasmothecia . Ascospore viability $\cdot$ Vitis vinifera

\section{Introduction}

Grape powdery mildew, caused by Erysiphe necator (Schw.) Burr. (syn. Uncinula necator), can overwinter as mycelium in infected buds of Vitis vinifera (Rügner et al. 2002) and as chasmothecia (formerly known as cleistothecia) (Pearson and Gadoury 1987). Buds on vines that were infected in the previous year will stay dormant until the following spring. After bud burst, the shoots that emerge from these buds, so-called flag shoots, are heavily covered with white colonies and conidia released from these colonies cause new infections (Rügner et al. 2002). In contrast, chasmothecia are formed on infected tissue in late summer and autumn (Pearson and Gadoury 1987). These fruiting bodies are then dispersed by rain to the exfoliating bark of vines in autumn (Legler et al. 2014). Ascospores are released from chasmothecia during rain events (Gadoury and 
Pearson 1990a) and cause primary infections on leaves in spring (Gadoury and Pearson 1990b).

Flag shoots are common in regions with relatively warm winter temperatures, such as in California (Ypema and Gubler 2000), France (Péros et al. 2005), Iran (Khiavi et al. 2012), Italy (Hajjeh et al. 2008), South Africa (Halleen and Holz 2000) and Spain (Núñez et al. 2006). They have also been found in cooler wine growing regions, such as Germany (Rügner et al. 2002) and South Tyrol (Haas and Denzer 1997), whereas cold winter temperatures $\left(<-12{ }^{\circ} \mathrm{C}\right)$ eliminate infected buds stressed by grapevine powdery mildew due to their reduced winter hardiness (Hill 1990). However, it is assumed that chasmothecia are the major source of inoculum in many parts of the world, such as New York (Pearson and Gadoury 1987), California (Gubler et al. 1988), in different regions of Italy (Cortesi et al. 1997; Rossi et al. 2010), Australia (Gee et al. 2000), France (Jailloux et al. 1998, 1999), South Africa (Halleen and Holz 2000), Washington (Grove 2004) and Hungary (Hoffmann and Viranyi 2007; Hoffmann et al. 2012). As reviewed by Gadoury et al. (2012) chasmothecia are important overwintering structures, moreover, following early chasmothecia development, the released ascospores can even result in infections in the same growing season.

The survival of chasmothecia requires a protective environment, such as leaf litter in mild-winter regions or the bark of vines in cold-winter regions (Gadoury et al. 2012). Accumulated wetting events and heat units can already reduce the inoculum quantity due to a high ascospore release from autumn until bud break, in particular, in milder climates (Moyer et al. 2014). In cooler central European grape growing regions, more precisely in South Tyrol and Germany, chasmothecia were originally reported to have been almost completely destroyed by microorganisms, and the released ascospores were considered to be not viable in spring (Denzer 1997; Moritz et al. 1997). Meanwhile in northern Italy, chasmothecia seem to be the major inoculum source in spring (Angeli et al. 2009; Rossi et al. 2011). In Austria only a negligible number of chasmothecia was found to overwinter on bark in the late 1990s, however the viability was not evaluated (Steinkellner 1998). Contrary to common assumptions, our own recent observations showed that chasmothecia are increasingly common in Austrian vineyards, suggesting that changing climate conditions, especially increasing temperatures, have fostered this development.
The effect of environmental conditions on chasmothecia development, ascospore release from chasmothecia, germination and infection of ascospores have been studied in-depth under controlled and field conditions (Gadoury and Pearson 1988, 1990a, b; Jailloux et al. 1998, 1999; Gee et al. 2000; Hajian et al. 2005; Rossi et al. 2010; Legler et al. 2012; Holb and Füzi 2016). However, only few studies (Diehl and Heintz 1987; Hajjeh et al. 2008) examined the effect of weather parameters on the viability of ascospores after overwintering. Those provide valuable information about the ascospore viability under defined laboratory conditions, but do not treat the effects of factual weather conditions in vineyards. Our objectives were to close this gap and to analyse the effect of temperature and precipitation, measured directly in the vineyard, on chasmothecia densities and viability of ascospores on bark and remaining leaf litter. We hypothesized that the local weather conditions in spring are the major driver for the survival and viability of ascospores in Austrians vine growing regions.

\section{Materials and methods}

Experimental sites and mildew occurrence

In April 2017 and 2018, chasmothecia of grape powdery mildew were investigated in commercial vineyards in three main Austrian grape-growing regions (Vienna, Lower Austria and Burgenland). The vineyards were planted with six different cultivars (Vitis vinifera $\mathrm{cv}$. Müller-Thurgau, Grüner Veltliner, Blauer Portugieser, Zweigelt, Chardonnay, Blaufränkisch, and Pinot blanc) and pruned to one or two canes per vine (4-8 buds $\mathrm{m}^{-2}$ ) in Guyot trellis systems with vertical shoot positioning. The age of the vineyards ranged from six to fifty-four years. The planting spacing was $1.4-3 \mathrm{~m}$ between the rows and $0.8-1.2 \mathrm{~m}$ within each row, and the heads of the vines were $0.7-1.2 \mathrm{~m}$ high. The vineyards in Vienna (Grüner Veltliner), Frauenkirchen (Zweigelt), Andau (Chardonnay) and St. Georgen (Pinot blanc) were managed organically. All others were managed according to the relevant Austrian rules for integrated pest management. No fungicides containing Ampelomyces quisqualis, a microbial hyperparasite of grape powdery mildew (Legler et al. 2016), were applied. Details on fungicide treatments against powdery mildew are given in Online Resource 1. 
In spring 2017 and 2018, vineyards with well-known but not quantified powdery mildew infections in Krems (Müller-Thurgau), Vienna (Grüner Veltliner) and Illmitz (Chardonnay 1) were inspected for the appearance of flag shoots and powdery mildew symptoms. Therefore, in plots not treated with fungicides against powdery mildew, 80-190 vines (depending on the individual size of the vineyard) were examined every 2-3 weeks between bud break and pea size (BBCH 09-75).

Weather stations (OTT Hydromet, Kempten, Germany) were positioned directly in the rows in vineyards in Krems (Grüner Veltliner), Frauenkirchen (Zweigelt), Illmitz (Chardonnay 1), Andau (Chardonnay), St. Georgen (Pinot blanc) and Großhöflein (Chardonnay) to measure temperature at cordon height $(0.8-1 \mathrm{~m})$, and precipitation over the canopy at 15-min intervals. Weather data were recorded for the whole period from August 2016 until end of April 2018.

\section{Chasmothecia collection and viability assessment}

Bark and leaf litter samples were taken between bud swell (BBCH 05) and bud break (BBCH 09) in 2017 and 2018. Bark samples were collected by brushing and peeling off the bark from the upper trunk according to Pearson and Gadoury (1987). Depending on the age of the vineyard (and thus the size of the trunks) 5-10 vines per experimental site were randomly chosen to obtain a minimum of $100 \mathrm{~g}$ per sample. Additionally, in 2017, all experimental sites were examined for leaf litter on the ground directly underneath the vines at the same date. Leaf litter was found and collected manually in vineyards in Krems (Müller Thurgau, Grüner Veltliner), Schrattenthal (Blauer Portugieser) and Andau (Chardonnay). All samples were stored at $+4{ }^{\circ} \mathrm{C}$ until used within 2 weeks. In order to obtain the chasmothecia from the bark samples, the method of Cortesi et al. (1995) was used. Twenty grams of each bark sample was placed in a 21 Erlenmeyer flask containing 11 tap water. The flask was shaken intensively for $3 \mathrm{~min}$, and the content was poured onto a $0.4 \mathrm{~mm}$ sieve placed over a $0.1 \mathrm{~mm}$ sieve. The material remaining on the $0.1 \mathrm{~mm}$ sieve was washed with distilled water in a measuring cylinder and poured into a beaker to yield a total of $50 \mathrm{ml}$. Two millilitres of the resulting suspension were pipetted onto a $9 \mathrm{~cm}$ diameter filter paper disc (VWR 417, Vienna, Austria) in four replicates. To remove the chasmothecia from the leaf litter, $20 \mathrm{~g}$ of dry material was ground by hand and then rubbed through a $0.9 \mathrm{~mm}$ sieve. One tenth of a gram of the sieved material that passed through the sieve was spread onto a Petri dish bottom with a counting grid $(0.5 \times 0.5 \mathrm{~mm})$. Chasmothecia from the leaf (in Petri dishes) and bark (on filter papers) samples were counted under a stereomicroscope at 30 -fold magnification.

For viability testing, filter papers containing chasmothecia were prepared as described above. Three replicates of 20 chasmothecia from each bark sample and 3 replicates of 25 chasmothecia from each leaf litter sample were examined microscopically. For vital staining a $0.5 \%(w / v)$ fluorescein diacetate solution (SigmaAldrich, St. Louis, USA) was prepared. For this purpose $5 \mathrm{mg}$ fluorescein diacetate was dissolved in $1 \mathrm{ml}$ acetone (stored at $-20^{\circ} \mathrm{C}$ ) at a ratio of 1:100 in distilled water, stored at $+4{ }^{\circ} \mathrm{C}$, and used for not more than $2 \mathrm{~h}$ (Vági et al. 2016). Chasmothecia were transferred by needle forceps onto glass slides with a drop of the fluorescein diacetate solution and cracked using a cover glass. Five minutes later, the glass slides were put under a fluorescence microscope and a fluorescein isothiocyanate (FTIC) fluorescence filter (excitation 456-495 nm, emission 515-555 nm) at 400-fold magnification. The number of viable ascospores (showing a bright green colour) per chasmothecium was recorded. A chasmothecium was classified as viable when at least one ascospore was viable. Chasmothecia were also inspected for the presence of A. quisqualis to evaluate parasitization effects.

The amount of viable ascospores per head of vine was calculated from the density of chasmothecia per $100 \mathrm{~g}$ bark, the number of viable ascospores per chasmothecium and the weight of the bark per head of vine (ranging between 5.8 and $9.0 \mathrm{~g}$ ).

\section{Viability experiment}

In October 2017, leaf samples were collected from a vineyard with a clearly visible high amount of chasmothecia. This vineyard (Research Center Jedlersdorf), comprising of different Vitis vinifera cultivars, had not been treated against powdery mildew after $\mathrm{BBCH}$ 79. Twenty-five leaves per sample were put in 1.51 plastic boxes, filled with $750 \mathrm{ml}$ of tap water and shaken intensively for $1 \mathrm{~min}$. The contents of altogether 60 plastic boxes were then poured onto a $0.4 \mathrm{~mm}$ sieve placed over a $0.1 \mathrm{~mm}$ sieve to collect chasmothecia. Subsequently, chasmothecia were diluted with distilled water. The resulting suspension containing about 950 
chasmothecia per $\mathrm{ml}$ was used for the viability experiment. For this purpose, $0.85 \mathrm{ml}$ of the suspension was pipetted on filter paper discs ( $9 \mathrm{~cm}$ diameter). Subsequently, the discs were transferred to Petri dishes and incubated at $7{ }^{\circ} \mathrm{C}$, representing the average temperature between chasmothecia development and bud break (August and April in Austria) and $17{ }^{\circ} \mathrm{C}$ (step of 10 as a comparison value), respectively, and watered every two weeks with $2 \mathrm{ml}$ of tap water. For each temperature and duration timepoint three replicates were prepared. The viability of 20 chasmothecia was assessed seven times, i.e. $8,12,16,20,24,26,30$ weeks after the start of the experiment on 3 filter paper discs of each temperature treatment as described above.

Inoculation experiment

Vines of the susceptible cultivar Müller-Thurgau were grown in a glasshouse equipped with a sulphur vaporizer operating once a day to ensure powdery mildewfree leaves. Detached leaves were prepared as described by Evans et al. (1996), although with slight modifications. The petiole was cut at the basal end, and the leaves were surface sterilized for 3-4 $\mathrm{min}$ in $0.5 \%$ sodium hypochlorite. Subsequently, the leaves were washed three times with distilled water.

The three bark samples with the greatest amounts of viable chasmothecia (Illmitz (Chardonnay 3, Blaufränkisch) and St. Georgen (Pinot blanc)) were then used to examine a possible infection with ascospores released from chasmothecia, based on a method adapted from (Grove 2004). Chasmothecia from bark were obtained as described above, with the exception that the chasmothecia were washed in $25 \mathrm{ml}$ instead of $50 \mathrm{ml}$ of distilled water. Subsequently, 1.0-2.5 $\mathrm{ml}$ of the suspension was pipetted onto the centre of a filter paper and examined under the microscope. The filter papers were adjusted to carry 25 chasmothecia.

Filter papers bearing chasmothecia were fixed with Vaseline ${ }^{\circledR}$ one each to the lid of a $9 \mathrm{~cm}$ diameter Petri dish, moistened with $1 \mathrm{ml}$ of distilled water and inverted over an above-described detached leaf (lower leaf surface facing upward) lying on a sterilized (in $70 \%$ ethanol) wire in a Petri dish bottom filled with $5 \mathrm{ml}$ of distilled water. Ten leaves per sample were prepared and 10 Petri dishes with a sterile filter paper bearing no chasmothecia attached to the lid served as the control. The Petri dishes were sealed with Parafilm and incubated at $25{ }^{\circ} \mathrm{C}$ for $18 \mathrm{~h}$ under light (= first incubation period). Then the leaves were transferred with the lower side facing upwards to other Petri dishes containing $1 \%$ water agar and further incubated at $25{ }^{\circ} \mathrm{C}$ and $70 \%$ relative humidity for 11 days under a daylight period of $16 \mathrm{~h}$. Control plates were treated the same way. After the second incubation period, the leaves were examined microscopically for the appearance of powdery mildew symptoms, and the number of colonies on each leaf was counted. The infection efficiency was calculated as percentage of successful infections (colonies on 10 leaves) in relation to the computed amount of viable ascospores in all 10 Petri dishes.

\section{Statistical analysis}

Statistical analysis was performed using R 3.5.1 (R Core Team 2018). Bark samples originating from all vineyards in Illmitz (Chardonnay 1, 2, 3, Grüner Veltliner and Blaufränkisch) were analysed with oneway ANOVA to test the effect of the cultivar on the number of chasmothecia and viable chasmothecia.

\section{Results}

Weather and mildew occurrence

At all experimental sites in plots not treated against powdery mildew, the first powdery mildew colonies were found on the abaxial sides of leaves in proximity to the bark between BBCH 55-73. Colonies appeared randomly throughout the observed vineyards. Our field monitoring revealed no flag shoots.

The mean temperature from August to the succeeding April ranged from 7.1 to $8.2{ }^{\circ} \mathrm{C}$ and from 7.3 to $8.4{ }^{\circ} \mathrm{C}$ in $2016 / 17$ and $2017 / 18$, respectively (Fig. 1). During both winters, the coldest mean temperatures were recorded in Krems, with an absolute minimum temperature of $-16.1{ }^{\circ} \mathrm{C}$ in January 2017 . In the overwintering season $2017 / 18$, the lowest absolute minimum temperatures occurred in March $\left(-15.5^{\circ} \mathrm{C}\right.$ at St. Georgen). The total precipitation from August to the succeeding April ranged from 254 to $413 \mathrm{~mm}$ and from 258 to $373 \mathrm{~mm}$ in 2016/17 and 2017/18, respectively. From September to October 2016, at St. Georgen the highest accumulated precipitation $(131 \mathrm{~mm})$ was 

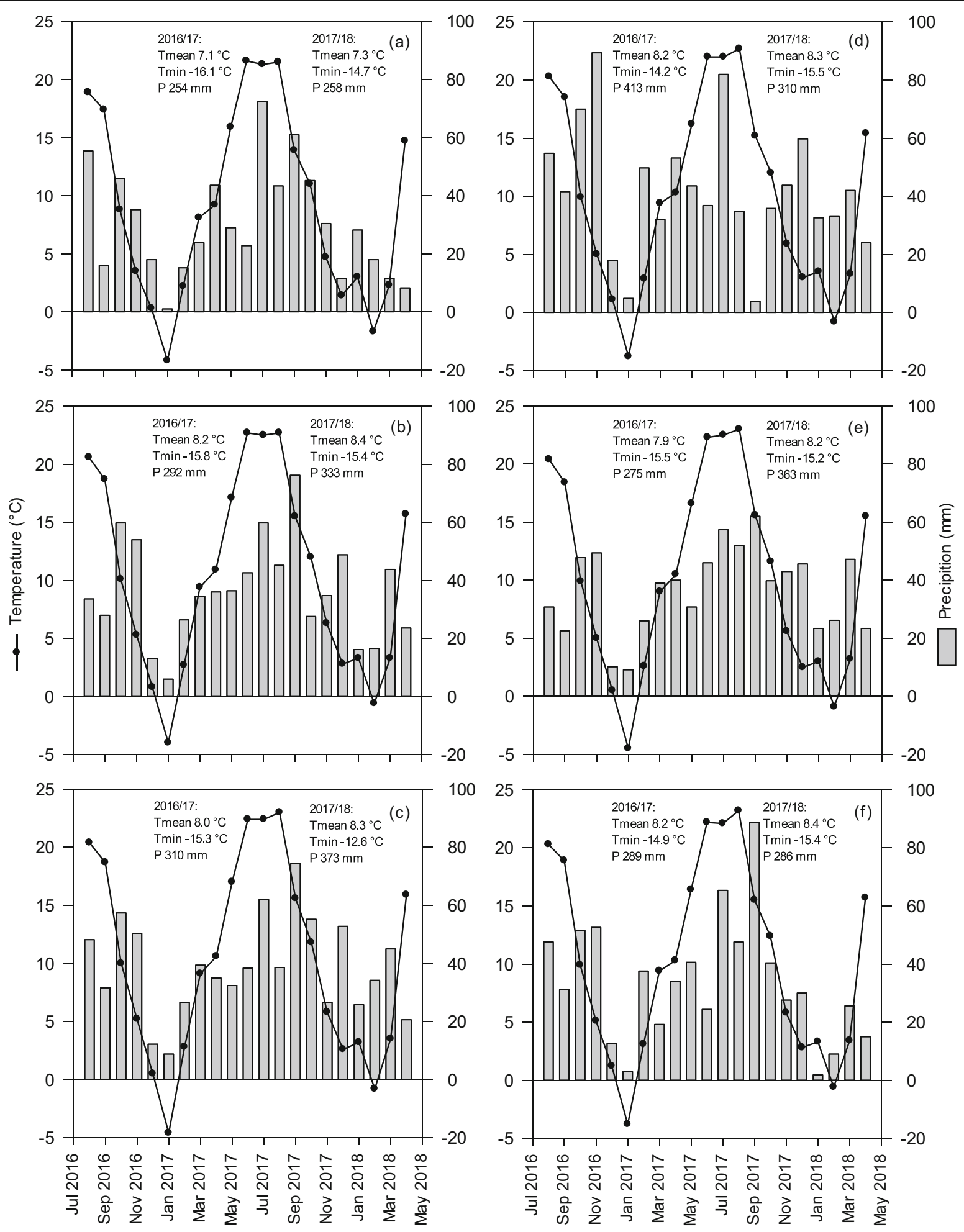

Fig. 1 Monthly average temperature (dots) and precipitation total (bars) at the locations Krems (Grüner Veltliner) (a), Illmitz (Chardonnay 1) (b), Andau (Chardonnay) (c), St Georgen (Pinot blanc) (d), Frauenkirchen (Zweigelt) (e), Großhöflein (f) from August

2016 to April 2018 and mean temperature (Tmean) minimum temperature (Tmin) and accumulated precipitation $(\mathrm{P})$ from $\mathrm{Au}-$ gust to April in the overwintering seasons 2016/17 and 2017/18 
measured while the lowest amount was recorded at Krems (62 mm). At the same period in 2017, most rain fell at Andau $(140 \mathrm{~mm})$ while at St. Georgen the sum was $40 \mathrm{~mm}$. The number of days with $>2 \mathrm{~mm}$ precipitation ranged between 21 (Großhöflein) to 32 (Andau) from August 2016 to April 2017 and between 31 (Krems) to 44 (Illmitz) in the same period in 2017/18.

Density of chasmothecia and viability of ascospores

The quantities ranged from 0 to 3656 chasmothecia per $100 \mathrm{~g}$ bark, with an average of 1168 chasmothecia, in 2017 , and from 0 to 2094, with an average of 854 , in 2018 (Table 1). High numbers of chasmothecia found in one vineyard in one year did not necessarily predict a high number of chasmothecia in the following year. Viable chasmothecia originating from bark were detected in all samples examined for viability except for the samples from Schrattenthal (Blauer Portugieser) in 2017 and from St. Georgen (Pinot blanc) in 2018. The amount of viable chasmothecia for all experimental sites reached a maximum of $26.7 \%$ in 2017 and $36.7 \%$ in 2018, respectively. The number of viable ascospores per head of vine ranged from 0 to 351 and from 0 to 251 in 2017 and 2018, respectively, and showed partly a strong variation within one location in both years. At Illmitz, the cultivar had a significant effect on the number of chasmothecia on the bark (one-way ANOVA; 2017: $\mathrm{df}=2, \mathrm{~F}=11.21, p<0001 ; 2018: \mathrm{df}=2, \mathrm{~F}=17.28$, $p<0.001)$ but no effect on the percentage of viable chasmothecia (one-way ANOVA; 2017: $\mathrm{df}=2$, $\mathrm{F}=0.573, p=0.578 ; 2018: \mathrm{df}=2, \mathrm{~F}=3.57, p=0.061$ ).

At four out of 13 experimental sites, leaf litter was present directly underneath the vines at bud break in 2017 (Table 2). All leaf litter samples showed a higher quantity of chasmothecia than the bark samples. The

Table 1 Number of chasmothecia (mean \pm SD) on exfoliating bark, their viability rate $(\% \pm S D)$ and the number of viable ascospores per head of vine in samples from 13 vineyards in spring 2017 and 2018

\begin{tabular}{|c|c|c|c|c|c|c|}
\hline \multirow[b]{2}{*}{ Location (cultivar) } & \multicolumn{3}{|l|}{2017} & \multicolumn{3}{|l|}{2018} \\
\hline & $\begin{array}{l}\text { Chasmothecia/ } \\
100 \mathrm{~g} \text { bark }\end{array}$ & $\begin{array}{l}\text { Viable } \\
\text { chasmothecia } \\
(\%)^{a}\end{array}$ & $\begin{array}{l}\text { Viable ascospores/ } \\
\text { head of vine }{ }^{a, b}\end{array}$ & $\begin{array}{l}\text { Chasmothecia/ } \\
100 \mathrm{~g} \text { bark }\end{array}$ & $\begin{array}{l}\text { Viable } \\
\text { chasmothecia } \\
(\%)^{a}\end{array}$ & $\begin{array}{l}\text { Viable ascospores/ } \\
\text { head of vine }{ }^{a, b}\end{array}$ \\
\hline $\begin{array}{l}\text { Krems } \\
\text { (Müller-Thurgau) }\end{array}$ & $188( \pm 72)$ & $6.70( \pm 6.11)$ & 4.62 & $1( \pm 1)$ & n.d. & n.d. \\
\hline $\begin{array}{l}\text { Krems (Grüner } \\
\text { Veltliner) }\end{array}$ & $31( \pm 63)$ & n.d. & n.d. & $750( \pm 270)$ & $13.33( \pm 7.64)$ & 40.95 \\
\hline $\begin{array}{l}\text { Schrattenthal (Blauer } \\
\text { Portugieser) }\end{array}$ & $2531( \pm 329)$ & $0.00( \pm 0.00)$ & 0.00 & $1250( \pm 468)$ & $11.67( \pm 5.77)$ & 70.88 \\
\hline $\begin{array}{l}\text { Vienna (Grüner } \\
\text { Veltliner) }\end{array}$ & $156( \pm 63)$ & $5.33( \pm 6.11)$ & 1.34 & $438( \pm 161)$ & $10.00( \pm 8.66)$ & 28.91 \\
\hline $\begin{array}{l}\text { Frauenkirchen } \\
\text { (Zweigelt) }\end{array}$ & $0( \pm 0)$ & n.d. & n.d. & $0( \pm 0)$ & n.d. & n.d. \\
\hline Illmitz (Chardonnay 1) & $594( \pm 157)$ & $8.00( \pm 0.00)$ & 16.92 & $1344( \pm 188)$ & $16.67( \pm 7.64)$ & 102.09 \\
\hline Illmitz (Chardonnay 2) & $1188( \pm 161)$ & $16.00( \pm 4.00)$ & 80.62 & $750( \pm 102)$ & $13.33( \pm 12.58)$ & 30.45 \\
\hline Illmitz (Chardonnay 3) & $2094( \pm 344)$ & $26.67( \pm 6.11)$ & 244.58 & $750( \pm 144)$ & $15.00( \pm 5.00)$ & 43.80 \\
\hline $\begin{array}{l}\text { Illmitz (Grüner } \\
\text { Veltliner) }\end{array}$ & $719( \pm 295)$ & $24.00( \pm 6.93)$ & 57.70 & $469( \pm 188)$ & $10.00( \pm 8.66)$ & 25.68 \\
\hline Illmitz (Blaufränkisch) & $2594( \pm 400)$ & $18.67( \pm 4.62)$ & 130.35 & $1625( \pm 177)$ & $26.67( \pm 7.64)$ & 186.47 \\
\hline Andau (Chardonnay) & $844( \pm 313)$ & $4.00( \pm 4.00)$ & 7.02 & $2094( \pm 313)$ & $36.67( \pm 2.89)$ & 250.61 \\
\hline $\begin{array}{l}\text { St. Georgen (Pinot } \\
\text { blanc) }\end{array}$ & $3656( \pm 483)$ & $21.33( \pm 2.31)$ & 350.76 & $781( \pm 258)$ & $0.00( \pm 0.00)$ & 0.00 \\
\hline $\begin{array}{l}\text { Großhöflein } \\
\text { (Chardonnay) }\end{array}$ & $594( \pm 120)$ & $4.00( \pm 4.00)$ & 4.63 & $844( \pm 258)$ & $21.67( \pm 2.89)$ & 65.83 \\
\hline
\end{tabular}

n.d. not determined

${ }^{\text {a }}$ Only shown for samples exceeding $>100$ chasmothecia/100 g bark

${ }^{\mathrm{b}}$ Viable ascospores per head of vine were calculated from the density of chasmothecia per $100 \mathrm{~g}$ bark, the number of viable ascospores per chasmothecium and the weight of the bark per head of vine 
Table 2 Number of chasmothecia (mean \pm SD) on leaf litter, their viability rate $(\% \pm \mathrm{SD})$ and the number of viable ascospores per chasmothecium (mean \pm SD) in spring 2017

\begin{tabular}{lccc}
\hline Location (cultivar) & Chasmothecia/100 g leaf litter & Viable chasmothecia $(\%)$ & Viable ascospores/ chasmothecium \\
\hline Krems (Müller-Thurgau) & $110,000( \pm 17,378)$ & $5.3( \pm 2.3)$ & $0.12( \pm 0.00)$ \\
Krems (Grüner Veltliner) & $5000( \pm 1414)$ & $0.0( \pm 0.0)$ & $0.00( \pm 0.00)$ \\
Schrattenthal (Bl. Portugieser) & $35,250( \pm 5377)$ & $0.0( \pm 0.0)$ & $0.00( \pm 0.00)$ \\
Andau (Chardonnay) & $43,500( \pm 10,149)$ & $0.0( \pm 0.0)$ & $0.00( \pm 0.00)$ \\
\hline
\end{tabular}

range was between 5000 and 110,000 chasmothecia per $100 \mathrm{~g}$ leaf litter. Viable ascospores were found in only one leaf litter sample, resulting in $5.3 \%$ viable chasmothecia. A single chasmothecium contained at most 4 viable ascospores.

\section{Viability experiment}

In the laboratory experiment on the effect of temperature on viability 8.23 and 4.08 viable ascospores per chasmothecium were detected at 7 and $17{ }^{\circ} \mathrm{C}$, respectively, after 8 weeks of exposure (Fig. 2). The viability decreased within the experimental period. At the end of the experiment (after 30 weeks) 0.48 ascospores per chasmothecium were found when stored at $7{ }^{\circ} \mathrm{C}$, at $17{ }^{\circ} \mathrm{C}$ no viable ascospores were determined.

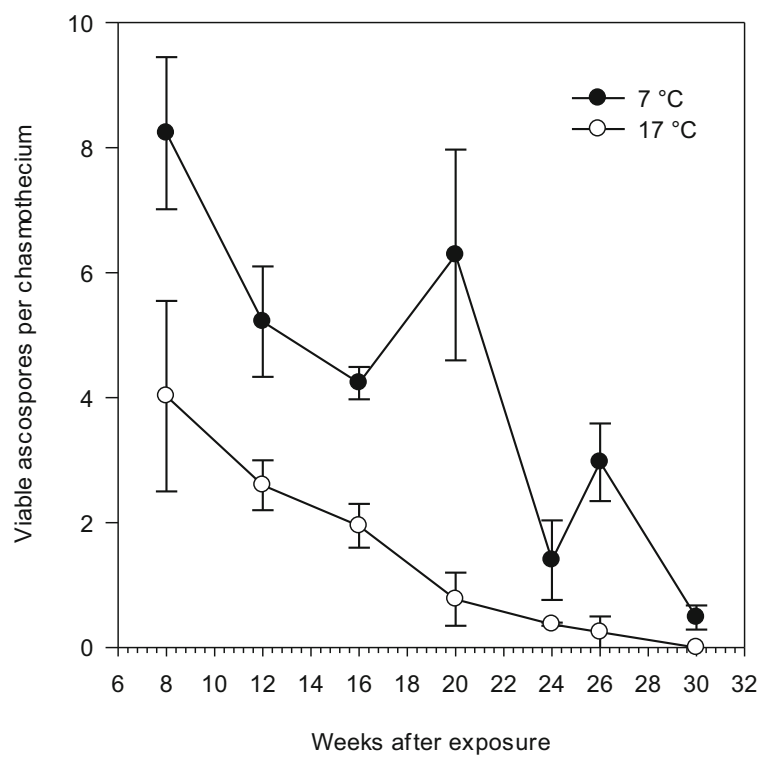

Fig. 2 Mean number of viable ascospores per chasmothecium $\left( \pm\right.$ SE) incubated at 7 and $17^{\circ} \mathrm{C}$
Inoculation experiment

Irrespective of the sampling location, ascospores in chasmothecia from bark material were able to infect leaves (Table 3). Three to six leaves (out of 10) showed colonies resulting in 7-12 colonies on a total of 10 leaves. All colonies produced conidia 12 days after inoculation. In the control treatment, no powdery mildew symptoms appeared on the leaves. The infection efficiency ranged between 2.4 and $6.6 \%$.

\section{Discussion}

Erysiphe necator is still one of the major diseases in grapevine. To develop and to apply the necessary measures to protect the vines, reliable regional data on the overwintering of powdery mildew are of great importance for the wine growers. In our study, no flag shoots were observed in Austrian vineyards in spring, and first powdery mildew signs were found on abaxial leaf surfaces, randomly distributed in the vineyards. This pattern is typical for ascosporic infections (Caffi et al. 2011). In our study, bark was the more frequent overwintering substrate compared to leaf litter. In 12

Table 3 Inoculation of detached leaves with chasmothecia from bark samples from Illmitz (Chardonnay 3, Blaufränkisch) and St.Georgen (Pinot blanc) in 2017

\begin{tabular}{llll}
\hline Location (cultivar) & $\begin{array}{l}\text { Leaves } \\
\text { with } \\
\text { colonies }\end{array}$ & $\begin{array}{l}\text { Colonies } \\
\text { on } 10 \\
\text { leaves }\end{array}$ & $\begin{array}{l}\text { Infection } \\
\text { efficiency } \\
(\%)^{\text {a }}\end{array}$ \\
\hline Illmitz (Chardonnay 3) & 6 & 12 & 3.0 \\
Illmitz (Blaufränkisch) & 4 & 11 & 6.6 \\
St. Georgen (Pinot blanc) & 3 & 7 & 2.4
\end{tabular}

${ }^{a}$ Infection efficiency was calculated as percentage of successful infections (colonies on 10 leaves) in relation to the computed amount of viable ascospores in 10 Petri dishes 
out of 13 vineyards chasmothecia were present on the exfoliating bark at bud break, whereas leaf litter was detected in only four vineyards in Austria in 2017. Our study depicts a high potential of chasmothecia production under Austrian organic and integrated pest management. On leaves, the chasmothecia densities (up to 110,000 per $g$ leaf litter) exceeded quantities that have been reported from other countries at bud break (up to 66,400 per $100 \mathrm{~g}$ material) (Cortesi et al. 1997; Magarey et al. 1997; Hajjeh et al. 2008). Our data indicate that high amounts of chasmothecia had been produced on leaves in the previous year. As we did not count the chasmothecia in autumn, we cannot report on their degradation rate during winter. However, previous reports have already shown that leaf litter largely decomposes during the winter months, natural parasitism can happen over the winter and the viability of chasmothecia on leaves drop down to a minimum (Gadoury and Pearson 1988). In most Austrian vineyards leaf litter decomposition had been completed at the time of bud break, as also described in New York (Pearson and Gadoury 1987). In contrast, in Australia leaves persist at high densities under trellises until bloom (Magarey et al. 1997). It can be assumed that leaf litter plays a minor role in overwintering and survival of $E$. necator in Austria for two main reasons: In Burgenland, fallen leaves are often transported out of vineyards by strong winds during winter. Moreover, in Austria, leaf litter is often incorporated into the soil under the vines by wine growers during mechanical weed control in autumn or at least in the following spring.

The transfer of chasmothecia to bark crevices by rain increases the survival rate in spring (Gadoury and Pearson 1988; Cortesi et al. 1997). In fact, in spring considerable quantities of chasmothecia were available in nearly all vineyards on bark. We found up to 3656 chasmothecia per $100 \mathrm{~g}$ exfoliating bark. This is in contrast to earlier studies (Steinkellner 1998) in Austrian vineyards, where only a very small number of chasmothecia was found on bark, indicating an increase in chasmothecia production within the last decades. However, our data are still within the range of the previously reported data from "cooler" grape growing regions such as Germany (up to 4350; Hill et al. 1995) or New York (up to 3200; Gadoury and Pearson 1988), but do not reach the high values of warmer regions such as Hungary (up to 31,207; Hoffmann et al. 2012), Central Italy (up to 6873; Cortesi et al. 1997), Southern Italy (up to 46,400; Hajjeh et al. 2008). In northern Italy up to
44 million chasmothecia/ha were found depending on the training system (Guyot, Geneva double curtain or spurred cordon pruning) (Rossi et al. 2011). In contrast, Austrian vines are mainly trained in Guyot trellis systems (pruned to one or two canes), with only negligible differences in the amount of bark per vine. Thus the calculated number of viable ascospores per vine was mainly based on the density of chasmothecia and the amount of viable ascospores per chasmothecia. We found between 0 and 351 viable ascospores per head of vine at bud break, although it must be noted, that some ascospores could have been released before bud break (Rossi et al. 2010).

In our study, marked differences were found between the examined vineyards and the two years, respectively. Chasmothecia quantity and viability on bark showed a high variability. This was also observed in Italy (Cortesi et al. 1997; Hajjeh et al. 2008) and Australia (Magarey et al. 1997). One reason for these results could be that the amount of chasmothecia produced on leaves was highly variable. A high quantity on bark can be related to a relatively high number of chasmothecia in the canopy in the previous season (Hoffmann et al. 2012). It is well known that temperature affects the development of chasmothecia, with the optimal development occurring at $20^{\circ} \mathrm{C}$ (Legler et al. 2012). In our study, the average temperatures at the vineyard sites from August to October, when most chasmothecia develop in Austria (Steinkellner and Redl 1998), were varying. The differences were most pronounced in 2017, when the mean temperature in August was clearly higher, and in September clearly lower than $20^{\circ} \mathrm{C}$. However, our data reveal that the conditions in Austria are suitable for the production of chasmothecia although weather data do not sufficiently explain the different level of chasmothecia production in the investigated vineyards.

As a result of the specific susceptibility the chasmothecia production varies among cultivars (Gadoury and Pearson 1988; Diehl and Heintz 1987; Hill et al. 1995). Although the investigated vineyards did not include mildew tolerant cultivars, our study shows some indication of a cultivar effect. However, looking at the cultivar Chardonnay the specific vineyard management seems to be more important. The variation in chasmothecia production could further be caused by differences among spray programmes in late summer (Hill et al. 1995; Steinkellner and Redl 1998), especially the date of the last spray before harvest (Moyer et al. 2014) or by the availability of compatible mating types 
(Gadoury and Pearson 1991). Chasmothecia initiation is delayed at low infection levels (Gadoury and Pearson 1991), so as a result of an early end of the spray program, the infestation intensity can increase and promote the formation of chasmothecia. Hence, the intense and long spray program at Frauenkirchen could explain why no chasmothecia were found in the bark in the following spring. As shown by Gadoury and Pearson (1988) chasmothecia are dispersed by rain only after hyphal necrosis and abscission of hyphal connection. Thus, a key point for the overwintering of large amounts of chasmothecia in bark could be the timing of maturation of ascoscarps and the intensity of rain events, which deposit the chasmothecia in bark cervices.

Only a small amount of chasmothecia originating from naturally overwintered leaf litter contained viable chasmothecia (maximum of 5\%), Our result is in accordance with findings from New York, Italy and Syria, showing a maximum of $10 \%$ viable chasmothecia on overwintered leaves at bud break (Gadoury and Pearson 1988; Cortesi et al. 1997; Hajjeh et al. 2008; Alimad et al. 2016). However, in Washington a percentage of $67 \%$ was observed on artificially overwintered leaf litter samples during this period (Grove 2004). It is possible that this overwintering form influenced the viability of the chasmothecia. During spring, the viability of chasmothecia on leaf litter rapidly decreases (Pearson and Gadoury 1987) and is affected by temperature (Hajjeh et al. 2008). Although the percentage of viable chasmothecia from leaves was low in the present study, their large quantity gave rise to a high amount of viable ascospores. However, as mentioned above, due to the common management practice leaf litter plays a minor role as inoculum source in Austria. In contrast to leaf litter, the percentage of viable chasmothecia in bark samples ranged from 0 to $36 \%$, whereby no natural hyperparasitism of chasmothecia from bark by A. quisqualis was observed. With the exception of samples from two vineyards (Schrattenthal and St. Georgen), all bark samples examined for viability had viable chasmothecia. One reason could be that, in contrast to other vineyards, at Schrattenthal wettable sulphur was sprayed late in the season in 2016 , reducing the viability of already developed chasmothecia. Sulphur based treatments are known to lower the viability of chasmothecia (Gadoury et al. 1994). However, this is not clearly supported by our data: Although it is a common practice in many Austrian regions to apply a sulphur spray at a high dose (2-3\%) against Calepitrimerus vitis and Eriophyes vitis at bud break, we found a sometimes high viability in these sulphur treated vineyards in spring.

For the wide range of viability in our results, Italian studies (6-68\% (Cortesi et al. 1997), 6-28\% (Hajjeh et al. 2008)) and US studies (45-86\%, (Pearson and Gadoury 1987; Gadoury and Pearson 1988)), the weather conditions and regional specificities have to be addressed. In our study, the weather conditions for overwintering clearly differed between both years. The minimum temperatures dropped below $-15{ }^{\circ} \mathrm{C}$ in both years, but the temperature and precipitation patterns during winter months differed considerably. However, from laboratory experiments it is known that chasmothecia lost their viability after 6 months of storage at $-5{ }^{\circ} \mathrm{C}$ and $-20{ }^{\circ} \mathrm{C}$ (Diehl and Heintz 1987). Hajjeh et al. (2008) found no viable chasmothecia after 4 months at 22 or $25{ }^{\circ} \mathrm{C}$, whereas after 7 months at 4 or $11{ }^{\circ} \mathrm{C}$ still $10 \%$ of the chasmothecia were still viable. In comparison, we studied the viability of ascospores based on the average temperature between chasmothecia production in autumn and bud break in the following spring $\left(7^{\circ} \mathrm{C}\right.$, August - April). The ascospores viability dropped down steadily and after 30 weeks at $17{ }^{\circ} \mathrm{C}$ no viable ascospores were detected, whereas chasmothecia incubated at $7{ }^{\circ} \mathrm{C}$ still contained a small amount of viable ascospores after this period. In our study, the viability rate of the ascospores after a similar time period in the field (at temperatures between 7.1 and $8.2{ }^{\circ} \mathrm{C}$ in 2017 and 7.3 and $8.4{ }^{\circ} \mathrm{C}$ in 2018) was in line with the obtained data in the laboratory experiments. It is unlikely that these marginal temperature distinctions caused the contrasts in the viability between the vineyards. However, future laboratory studies using temperature profiles close to field conditions will provide an even better approximation.

Anyway, ascospores overwintered on bark in the field were infectious, as shown by inoculation experiments with detached leaves. The infection efficiency of ascospores was low, as also found in other studies (Pearson and Gadoury 1987; Gadoury and Pearson 1990b; Evans et al. 1997; Magarey et al. 1997; Jailloux et al. 1998; Grove 2004). In our study up to 350 viable ascospores per vine were available 
at bud break and thus can constitute a high potential to infect grapevine leaves. This is supported by Holb and Füzi (2016) who found a clear relationship between the number of released ascospores between bud break and bloom and disease severity on grapes. However, it has been pointed out that the release of ascospores requires appropriate environmental conditions, in particular sufficient precipitation (Gadoury and Pearson 1990a; Jailloux et al. 1999; Rossi et al. 2010; Holb and Füzi 2016).

Our results point towards a minor effect of the local environmental conditions on the differences in survival and viability of ascospores between vineyards, whereas management practices seem to play a key role in the available number of viable ascospores at bud break. Reduction of the ascospore viability by management practices, like sulphur sprays at bud break (as used in our study by winegrowers), or pre- and postharvest sprays with Ampelomyces quisqualis or fungicides (Caffi et al. 2013), should be taken into account when determining fungicide applications. Such eradication treatments can delay the onset of disease development up to several weeks (Gadoury et al. 1994) and can allow a later start of the fungicide treatments against powdery mildew with a lesser number of sprays per season. Therefore, a better understanding of the effect of individual management actions in the vineyards on the survival and viability of ascopores of E. necator is still necessary to optimize decision support systems, thus contributing to a sustainable viticulture.

Supplementary Information The online version contains supplementary material available at https://doi.org/10.1007/s10658020-02192-6.

Acknowledgements The authors thank the grape growers for providing their vineyards as research sites and Georg Mich and Lina Weissengruber for technical assistance. We are grateful to Karin Hage-Ahmed for critical reading of the manuscript.

Funding Open Access funding provided by University of Natural Resources and Life Sciences Vienna (BOKU).

\section{Compliance with ethical standards}

Conflict of interest The authors declare that they have no conflict of interest.

Human and animals rights No human and/or animal participants were involved in this research.
Informed consent All authors consent to this submission.

Open Access This article is licensed under a Creative Commons Attribution 4.0 International License, which permits use, sharing, adaptation, distribution and reproduction in any medium or format, as long as you give appropriate credit to the original author(s) and the source, provide a link to the Creative Commons licence, and indicate if changes were made. The images or other third party material in this article are included in the article's Creative Commons licence, unless indicated otherwise in a credit line to the material. If material is not included in the article's Creative Commons licence and your intended use is not permitted by statutory regulation or exceeds the permitted use, you will need to obtain permission directly from the copyright holder. To view a copy of this licence, visit http://creativecommons.org/licenses/by/4.0/.

\section{References}

Alimad, N., Naffaa, W., \& Azmeh, F. (2016). Initiation and development of Erysiphe necator chasmothecia and their role in the epidemiology of grapevine powdery mildew in southern Syria. Acta Mycologica, 51(2), 1-11. https://doi. org/10.5586/am.1088.

Angeli, D., Pellegrini, E., \& Pertot, I. (2009). Occurrence of Erysiphe necator chasmothecia and their natural parasitism by Ampelomyces quisqualis. Phytopathology, 99(6), 704 710. https://doi.org/10.1094/PHYTO-99-6-0704.

Caffi, T., Rossi, V., Legler, S. E., \& Bugiani, R. (2011). A mechanistic model simulating ascosporic infections by Erysiphe necator, the powdery mildew fungus of grapevine. Plant Pathology, 60(3), 522-531. https://doi.org/10.1111 j.1365-3059.2010.02395.x.

Caffi, T., Legler, S. E., Bugiani, R., \& Rossi, V. (2013). Combining sanitation and disease modelling for control of grapevine powdery mildew. European Journal of Plant Pathology, 135(4), 817-829. https://doi.org/10.1007 /s10658-012-0124-0.

Cortesi, P., Gadoury, D. M., Seem, R. C., \& Pearson, R. C. (1995). Distribution and retention of cleistothecia of Uncinula necator on the bark of grapevines. Plant Disease, 79(1), 15-19. https://doi.org/10.1094/PD-79-0015.

Cortesi, P., Bisiach, M., Ricciolini, M., \& Gadoury, D. M. (1997). Cleistothecia of Uncinula necator - an additional source of inoculum in Italian vineyards. Plant Disease, 81(8), 922926. https://doi.org/10.1094/PDIS.1997.81.8.922.

Denzer, H. (1997). Cleistothecia formation and parasitation of Uncinula necator in South Tyrol. Viticulture and Enology Sciences, 52(3), 199.

Diehl, H. J., \& Heintz, C. (1987). Studies on the generative reproduction of grapevine powdery mildew (Uncinula necator Berk.). Vitis, 26(2), 114-122.

Evans, K. J., Whisson, D. L., \& Scott, E. S. (1996). An experimental system for characterizing isolates of Uncinula necator. Mycological Research, 100(6), 675-680. https://doi.org/10.1016/S0953-7562(96)80197-3. 
Evans, K. J., Scott, E. S., \& Whisson, D. L. (1997). Heterothallism among south Australian clonal lines of Uncinula necator. Australasian Plant Pathology, 26(1), 10-20. https://doi. org/10.1071/AP97002.

Gadoury, D. M., \& Pearson, R. C. (1988). Initiation, development, dispersal, and survival of cleistothecia of Uncinula necator in New York vineyards. Phytopathology, 78(11), 1413-1421.

Gadoury, D. M., \& Pearson, R. C. (1990a). Ascocarp dehiscence and ascospore discharge in Uncinula necator. Phytopathology, 80(4), 393-401. https://doi.org/10.1094 /Phyto-80-393.

Gadoury, D. M., \& Pearson, R. C. (1990b). Germination of ascospores and infection of Vitis by Uncinula necator. Phytopathology, 80(11), 1198-1203. https://doi. org/10.1094/Phyto-80-1198.

Gadoury, D. M., \& Pearson, R. C. (1991). Heterothallism and pathogenic specialization in Uncinula necator. Phytopathology, 81(10), 1287-1293. https://doi. org/10.1094/Phyto-81-1287.

Gadoury, D. M., Pearson, R. C., Riegel, D. G., Seem, R. C., Becker, C. M., \& Pscheidt, J. W. (1994). Reduction of powdery mildew and other diseases by over-the-trellis applications of lime sulfur to dormant grapevines. Plant Disease, 78(1), 83-87.

Gadoury, D. M., Cadle-Davidson, L., Wilcox, W. F., Dry, I. B., Seem, R. C., \& Milgroom, M. G. (2012). Grapevine powdery mildew (Erysiphe necator): A fascinating system for the study of the biology, ecology and epidemiology of an obligate biotroph. Molecular Plant Pathology, 13(1), 1-16. https://doi.org/10.1111/j.1364-3703.2011.00728.x.

Gee, L. M., Stummer, B. E., Gadoury, D. M., Biggins, L. T., \& Scott, E. S. (2000). Maturation of cleistothecia of Uncinula necator (powdery mildew) and release of ascospores in southern Australia. Australien Journal of Grape and Wine Research, 6(1), 13-20.

Grove, G. G. (2004). Perennation of Uncinula necator in vineyards of eastern Washington. Plant Disease, 88(3), 242-247. https://doi.org/10.1094/PDIS.2004.88.3.242.

Gubler, W. D., Fogle, D. G., \& Chellemi, D. O. (1988). Viability and pathogenicety of Uncinula necator ascospores in California (Abstr.). Phytopathology, 78(12), 1572.

Haas, E., \& Denzer, H. (1997). The occurence of flag shoots in South Tyrol. Viticulture and Enology Sciences, 52(3), 209.

Hajian, M., Zad, J., Tehrani, A. S., Okhovvat, M., \& Safarnezhad, A. (2005). Effect of environmental conditions on release, germination and pathogenicity of ascospores in Uncinula necator, the casual agent of grape powdery mildew. Iranian Journal of Agriculture Science, 36(1), 121-128.

Hajjeh, H., Miazzi, M., \& Faretra, F. (2008). Overwintering of Erysiphe necator Schw. In southern Italy. Journal of Plant Pathology, 90(2), 323-330.

Halleen, F., \& Holz, G. (2000). Cleistothecia and flag shoots: Sources of primary inoculum for grape powdery mildew in the Western Cape Province, South Africa. South African Journal of Enology and Viticulture, 21(2), 66-70.

Hill, G. K. (1990). The influence of annual weather patterns on epidemics of Uncinula necator in Rheinhessen. Viticulture and Enology Sciences, 45, 43-46.

Hill, G. K., Baumberger, I., \& Spies, S. (1995). Studies on occurrence of the cleistothecia of Uncinula necator (Schw.) Burr. in two vinegrowing areas of Germany. Viticulture and Enology Sciences, 50(1), 3-8.

Hoffmann, P., \& Viranyi, F. (2007). The occurrence of cleistothecia of Erysiphe necator (grapevine powdery mildew) and their epidemiological significance in some vinegrowing regions of Hungary. Acta Phytopathologica et Entomologica Hungarica, 42(1), 9-16. https://doi. org/10.1556/APhyt.42.2007.1.2.

Hoffmann, P., Füzi, I., \& Viranyi, F. (2012). Indirect effect of fungicide treatments on chasmothecia of Erysiphe necator Schwein overwintering on grapevine bark. Plant Protection Science, 48(1), 21-30. https://doi.org/10.1080 $/ 146349801753569252$.

Holb, I. J., \& Füzi, I. (2016). Monitoring of ascospore density of Erysiphe necator in the air in relation to weather factors and powdery mildew development. European Journal of Plant Pathology, 144(4), 751-762. https://doi.org/10.1007 /s10658-015-0823-4.

Jailloux, F., Thind, T., \& Clerjeau, M. (1998). Release, germination, and pathogenicity of ascospores of Uncinula necator under controlled conditions. Canadian Journal of Botany, 76(5), 777-781. https://doi.org/10.1139/b98-054.

Jailloux, F., Willocquet, L., Chapuis, L., \& Froidefond, G. (1999). Effect of weather factors on the release of ascospores of Uncinula necator, the cause of grape powdery mildew, in the Bordeaux region. Canadian Journal of Botany, 77(7), 1044-1051.

Khiavi, H. K., Shikhlinskiy, H., Ahari, A. B., \& Akrami, M. (2012). Study on the biology and epidemiology of Uncinula necator the causal agent of grape powdery mildew disease. Life Science Journal, 9(3), 1787-1792.

Legler, S. E., Caffi, T., \& Rossi, V. (2012). A nonlinear model for temperature-dependent development of Erysiphe necator chasmothecia on grapevine leaves. Plant Pathology, 61(1), 96-105. https://doi.org/10.1111/j.1365-3059.2011.02498.x.

Legler, S. E., Caffi, T., \& Rossi, V. (2014). A model for the development of Erysiphe necator chasmothecia in vineyards. Plant Pathology, 63(4), 911-921. https://doi.org/10.1111 /ppa.12145.

Legler, S. E., Pintye, A., Caffi, T., Gulyás, S., Bohár, G., Rossi, V., \& Kiss, L. (2016). Sporulation rate in culture and mycoparasitic activity, but not mycohost specificity, are the key factors for selecting Ampelomyces strains for biocontrol of grapevine powdery mildew (Erysiphe necator). European Journal of Plant Pathology, 144(4), 723-736. https://doi. org/10.1007/s10658-015-0834-1.

Magarey, P. A., Gadoury, D. M., Emmett, R. W., Biggins, L. T., Clarke, K., Wachtel, M. F., et al. (1997). Cleistothecia of Uncinula necator in Australia. Viticulture and Enology Sciences, 52(3), 210-218.

Moritz, C., Zinkernagel, V., \& Kassemeyer, H. H. (1997). Investigations on release and germination of ascospores of Uncinula necator in south-West Germany. Viticulture and Enology Sciences, 52(3), 219.

Moyer, M. M., Gadoury, D. M., Wilcox, W. F., \& Seem, R. C. (2014). Release of Erysiphe necator ascospores and impact of early season disease pressure on Vitis vinifera fruit infection. American Journal of Enology and Viticulture, 65(3), 315-324. https://doi.org/10.5344 /ajev.2014.13111. 
Núñez, Y., Gallego, J., Ponz, F., \& Raposo, R. (2006). Analysis of population structure of Erysiphe necator using AFLP markers. Plant Pathology, 55(5), 650-656. https://doi. org/10.1111/j.1365-3059.2006.01435.x.

Pearson, R. C., \& Gadoury, D. M. (1987). Cleistothecia, the source of primary inoculum for grape powdery mildew in New York. Phytopathology, 77(11), 1509-1514.

Péros, J. P., Troulet, C., Guerriero, M., Michel-Romiti, C., \& Notteghem, J. L. (2005). Genetic variation and population structure of the grape powdery mildew fungus, Erysiphe necator, in southern France. European Journal of Plant Pathology, 113(4), 407-416. https://doi.org/10.1007 /s10658-005-4563-8.

R Core Team (2018). R: A language and environment for statistical computing. R Foundation for Statistical Computing, Vienna. [https://www.R-project.org/].

Rossi, V., Caffi, T., \& Legler, S. E. (2010). Dynamics of ascospore maturation and discharge in Erysiphe necator, the causal agent of grape powdery mildew. Phytopathology, 100(12), 1321-1329. https://doi.org/10.1094/PHYTO-05-10-0149.

Rossi, V., Caffi, T., Legler, S. E., Bugiani, R., \& Frisullo, P. (2011). Dispersal of the sexual stage of Erysiphe necator in northern Italy. IOBC/wprs Bulletin, 67, 115-121.
Rügner, A., Rumbolz, J., Huber, B., Bleyer, G., Gisi, U., Kassemeyer, H.-H., \& Guggenheim, R. (2002). Formation of overwintering structures of Uncinula necator and colonization of grapevine under field conditions. Plant Pathology, 51(3), 322-330.

Steinkellner, S. (1998). Overwintering of Uncinula necator in Austrian vineyards. Vitis, 37(4), 193-194.

Steinkellner, S., \& Redl, H. (1998). Untersuchungen zur Kleistothezienentwicklung des Echten Rebenmehltaus unter österreichischen Produktionsbedingungen. Mitteilungen Klosterneuburg, 48(1), 17-24.

Vági, P., Caffi, T., Váczy, K. Z., Németh, M. Z., \& Kiss, L. (2016). Refining a method for ascospore viability testing in overwintering chasmothecia of Erysiphe necator. European Journal of Plant Pathology, 144(4), 799-802. https://doi. org/10.1007/s10658-015-0797-2.

Ypema, H. L., \& Gubler, W. D. (2000). The distribution of early season grapevine shoots infected by Uncinula necator from year to year : A case study in two California vineyards. American Journal of Enology and Viticulture, 51(1), 1-6. 